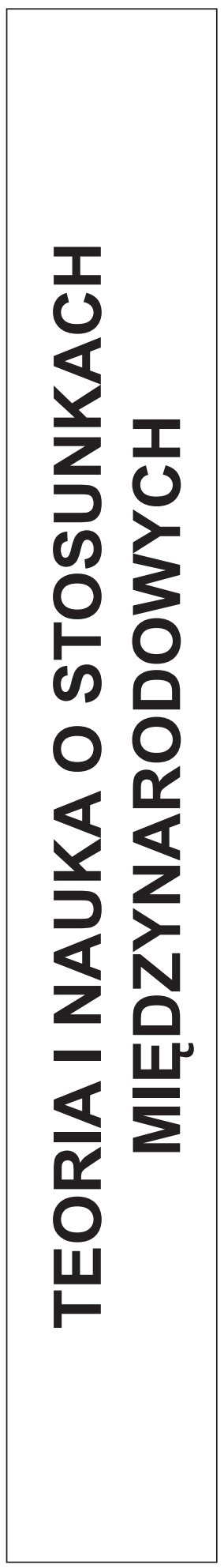





\title{
TEORIE STOSUNKÓW MIĘDYNARODOWYCH W STRUKTURZE WIEDZY HUMANISTYCZNEJ O SYSTEMIE ŚWIATOWYM (cywilizacji światowej)
}

\begin{abstract}
W artykule rozważany jest problem integracji wiedzy humanistycznej, koniecznej do opisu struktury i funkcjonowania współczesnej cywilizacji. Wiedza ta gromadzona jest $\mathrm{w}$ instytucjonalnych ramach różnych dyscyplin nauk społecznych. Paradoksalnie stosunkowo mało eksponowane miejsce w podziale pracy badawczej zajmuje nauka o stosunkach międzynarodowych. Jej domeną - w dotychczasowym kształcie - jest bowiem aspekt relacji między państwami, rozumianymi jako suwerenne jednostki geopolityczne. Większe inspiracje i walory heurystyczne zawiera dorobek world history (W. McNeill, J. Goody, K. Pomerantz), makrohistorycznej socjologii (P. Burke, M. Mann, Ch. Tilly) czy teorii systemów-światów F. Braudela czy I. Wallersteina. $\mathrm{W}$ artykule przedstawiona jest $\mathrm{w}$ zarysie transdyscyplinowa strategia badania cywilizacji światowej.
\end{abstract}

\section{TRANSDYSCYPLINOWA STRATEGIA BADANIA CYWILIZACJI ŚWIATOWEJ}

Można wstępnie określić system światowy, inaczej cywilizację światową, jako całość dynamiczną, która jest złożeniem ogółu społeczeństw narodowych i/lub cywilizacji lokalnych, czyli dodatkową n+1 strukturą. Żeby mówić o całości dynamicznej, muszą zachodzić oddziaływania i warunkowania między społeczeństwami narodowymi, ich podstrukturami (gospodarkami, państwami, kulturami narodowymi).

W sferze gospodarczej mamy takie sieci powiązań jak:

- zintegrowane globalne łańcuchy produkcyjne, ich ogniwami pozostają np. producenci komponentów, wielkie gospodarstwa rolne oraz wielcy detaliści, służący globalnemu supermarketowi konsumentów wywodzących się z klas średnich; przepływy kapitału finansowego, wymianę handlową, pod egidą WTO, która dąży do ekspansji i hegemonii np. korporacyjnego rolnictwa przemysłowego, instytucjonalizując zasady wolnego handlu i monopolistycznych praw własności intelektualnej, migracje siły roboczej, eksport technologii i innowacji organizacyjnych. Ale również hierarchie korzyści z wymiany gospodarczej, będącej efektem odmiennych dyferencjałów produktywności pracy, miejsca w międzynarodowym podziale pracy i światowego bogactwa, słowem, światowego systemu nowoczesnej gospodarki rynkowo-kapitalistycznej z jej bogatym, dominującym technologicznie centrum, semiperyferiami 
i peryferiami; reżimy handlu międzynarodowego WTO czy normy i sankcje chroniące własność intelektualną;

- w sferze politycznej będą to relacje i oddziaływania państw, chroniących bezpieczeństwa swego narodu i bezpieczeństwa światowego (sojusze, ład międzynarodowy, zmniejszanie zagrożeń ruchów politycznych posługujących się terrorem, przestępczości zorganizowanej, nielegalnej migracji). Współcześnie najważniejsza jest funkcja systemowa polegająca na wspólnym regulowaniu i koordynacji wykorzystywania globalnych dóbr kolektywnych oraz regulowanie procesów gospodarczych, żeby stworzyć instytucjonalne warunki trwałego rozwoju cywilizacji ogólnoludzkiej. W tym celu państwa tworzą nowe instytucjonalne reżimy dla takiej współpracy i współdziałania jak G-20, a także narzędziem ich sterujących oddziaływań są dotychczasowe organizacje międzynarodowe jak Bank Światowy, Międzynarodowy Fundusz Walutowy czy Międzynarodowa Organizacja Handlu oraz wiele organizacji tworzących system ONZ. Państwa wykorzystując różne instrumenty ekonomiczne tworzą warunki brzegowe funkcjonowania na podległym sobie terytorium przedsiębiorstw zagranicznych i ponadnarodowych korporacji i inwestycji bezpośrednich i portfelowych, starając się podnieść konkurencyjność narodowej gospodarki;

- w sferze kultury duchowej dochodzi do spotkań i konfrontacji różnych kultur narodowych, Hollyworld - światowa popkultura made in Hollywood-miesza się z world music, dominacja, a nawet imperializm kulturowy (jak narzucanie standardów nauki anglosaskiej całemu światu) z jednej strony, z drugiej zaś - odkrywanie i wzbogacanie płytotek, recept kuchennych, wrażliwości estetycznej dorobkiem peryferyjnych narodów czy cywilizacji lokalnych. Ważnym problemem jest poznanie i zrozumienie Innych - ich światopoglądów, systemów wartości, religii, kultury społecznej; dostrzeżenie potrzeby relatywizacji kulturowej i przezwyciężenie - w Europie - europocentryzmu i innych „centryzmów”, fundamentalizmów, resentymentów. W ciągu dziesięciu tysięcy lat rozwoju cywilizacji lokalnych nie tylko geny mieszały się prowadząc do stopniowego zaniku różnic rasowych; postępuje też metysaż kulturowy, ludzie wracają na łono wielkiej rodziny; stajemy się coraz bardziej zintegrowanym gatunkiem globalnym;

- w relacjach z przyrodą chodzi o przestrzeń ludzkiego świata, wyznaczoną przez techniczne przedłużenia rąk ludzkich. W obecnej fazie społeczeństwa przemysłowego tak szeroko objęła ona środowisko przyrodnicze, że współcześnie nie można uprawiać refleksji nad życiem społecznym, nie uwzględniając kategorii i wiedzy nauk przyrodniczych, a nawet technicznych. I odwrotnie: także reprezentanci dyscyplin przyrodniczych dostrzegają konieczność włączenia do swoich analiz kategorii i wiedzy politologicznej ${ }^{1}$.

Dlatego kolejnym systemem, bez którego nie można zrozumieć funkcjonowania cywilizacji światowej jest globalny ekosystem, i nauki opisujące jego funkcjonowanie.

1 Np. S. H. Schneider, Laboratorium Ziemia, Warszawa 1998, s. 13; J. Diamond, Strzelby, zarazki, maszyny, Warszawa 2010, s. 23; H. Rogall, Ekonomia zrównoważonego rozwoju. Teoria i praktyka, Poznań 2010, s. 140, 541; F. Fernandez-Armesto, Cywilizacje. Kultura, ambicje i przekształcanie natury, Warszawa 2008, s. 33-34. 
Połączenie tych perspektyw badania tworzy strategię transdyscyplinową rekonstrukcji najważniejszych czynników i uwarunkowań procesu historycznego - jednostkowego procesu zazębiania się i scalania dziejów cywilizacji lokalnych, ich trwania, zaniku i rozwoju. O systemie światowym możemy mówić dopiero w epoce odkryć geograficznych, po przyłączeniu cywilizacji prekolumbijskich. Najpierw powstał światowy rynek, później- po ujawnieniu się skutków rewolucji przemysłowej - światowa gospodarka kapitalistyczna. Wówczas bowiem mamy do czynienia z jakościowo nową mega makrostrukturą - cywilizacją światową. Ukształtowała ją pogoń za rentą przez konkurujących ze sobą kupców, przedsiębiorców, teraz ponadnarodowe firmy. Szukali oni - i na ogół znajdowali - tanich towarów i surowców, rynków zbytu i lokat kapitału, w sumie - pomnażali bogactwo pieniężne. Im głównie zawdzięczamy świat, jaki znamy, bez względu na to, czy nam się on podoba bardzo, czy trochę mniej, a nawet wcale.

W takim razie cywilizacja światowa to największa możliwa całość złożona z państw narodowych i systemu międzypaństwowego; narodów i cywilizacji lokalnych; łańcuchów produkcyjnych w przemyśle i w rolnictwie, a także globalnego systemu finansowego gospodarki-świata; procesów wymiany kulturowej (hybrydyzacji kultur); globalnego systemu ekologicznego. W obecnej postaci powstał on w wyniku interakcji między populacją ludzką (głównie za pośrednictwem techniki i pracy) a przyrodą; efektem tych tysiącletnich interakcji jest zhumanizowana przyroda: techniczno-przyrodnicze środowisko egzystencji ludzi. Ono z kolei jest fragmentem jeszcze szerszej całości przyrodniczej: systemu Ziemia, nie wiadomo czy przyjazną matką - Gają czy wręcz przeciwnie - zabójczą Medeą.

Refleksja nad przyczynami przełomowych zmian struktur życia społecznego przybrała postać wielu odmiennych schematów interpretacyjnych. Rozmaicie rozwiązują one problemy badawcze, które nastręcza taka uogólniająca refleksja. Do najważniejszych należą:

a) problem Wallersteina - strategii transdyscyplinowej, przezwyciężającej dziewiętnastowieczne podziały nauk społecznych na trzy „,suwerenne królestwa” - ekonomię, politologię i socjologię;

b) problem Sztompki - struktura a działanie; chodzi o spójne połączenie w procesie badawczym i procedurach badania zewnętrznych warunków działania podmiotów społecznych, na których podłożu kształtuje się jedna z możliwych alternatyw działania; wybór konkretnej alternatywy zależy od uruchomionej przez podmiot wiedzy o tych warunkach oraz wyznawanych systemów wartości. Przy czym podmiotowość w ujęciu M. Archer to refleksyjność, sprawstwo, innowacyjność, celowość. Badaczka ta osadziła relację podmiot-struktura w czasie historycznym. Podstawowym motorem zmiany jest moc podmiotowa jednostek ludzkich i zbiorowości. W tej szeroko stosowanej w praktyce wyjaśniania działań ludzkich koncepcji cykl morfogenetyczny to naprzemienne fazy strukturalnej determinacji i podmiotowej kreatywności ${ }^{2}$;

2 Zob.: M. Archer, Realist Social Theory: The Morphogenetic Approach, Cambridge 1996, s. 71 i n.; P. Sztompka, Socjologia zmian społecznych, Kraków 2005, s. 190-191; S. McAnulla, Struktura a podmiotowość, w: Teorie i metody w naukach politycznych, red. D. March, D. Stocker, Kraków 2006, s. 287-292. 
c) problem Braudela - jak wyodrębniać całości - systemy; chodzi o wybór systemów względnie izolowanych, zawierających wszystkie konieczne i wystarczające warunki, potrzebne do zrozumienia interesujących badacza całości społecznych i procesów, które w nich zachodzą. Czasami wystarczy ograniczyć uwagę do wybranej podstruktury życia społecznego, np. świadomości społecznej czy gospodarki. Ale na ogół trzeba wyodrębnić minisystemy, imperia, ekosystemy czy regiony, a nawet dla niektórych procesów systemy kontynentalne czy całą ekumenę;

d) problem Blauta - jak unikać europocentryzmu, czyli konwencjonalnej wiedzy, często poza empiryczną kontrolą, wynikającej z przekonania o europejskim ekscepcjonalizmie - roli europejskiej racjonalności, nauki, indywidualizmu w powstaniu obecnej cywilizacji miejsko-przemysłowej. Przekonanie to nie dowartościowuje dorobku technologicznego, kulturowego pozostałych cywilizacji lokalnych, zwłaszcza chińskiej, indyjskiej i islamsko-arabskiej;

e) problem Hegla, Kozyr-Kowalskiego: ciagłości/zmiany (kainotyzmu); w procesie zmiany powstają nowe jakościowo formy życia społecznego, zmieniające dotychczasowe determinanty procesów społecznych. Fakt ten sprawia, że prawa nauk społecznych, wraz z stosowanymi w nich pojęciami muszą uwzględniać rozwojowy aspekt rzeczywistości historycznej. Ich ogólność polega na uwzględnianiu różnic strukturalnych, występujących między wszystkimi dotychczasowymi typami zjawisk społecznych, które opisują (ogólność w sensie historycznym a nie teoriomnogościowym);

f) problem Parsonsa - holizmu, uwarunkowań strukturalnych: ekologicznych, demograficznych, gospodarczych, politycznych, kulturowych i ich różnej mocy determinacyjnej. Żeby należycie uwypuklić w procesie badawczym ich zróżnicowane znaczenie i odmienność mechanizmów wzajemnego oddziaływania, trzeba rozporządzać odpowiednimi koncepcjami czy teoriami. Wówczas przyjmowane przez badacza założenia ontologiczne i epistemologiczne prowadzą do tych fragmentów rzeczywistości społecznej i postulowanych związków pomiędzy nimi, które mogą okazać się zgodne z przyjmowanym obrazem społecznego świata bądź nie. Zapewnia to badaniom zmian społecznych z jednej strony niezbędną wszechstronność ujęcia, a z drugiej - empiryczny, chociaż niekiedy bardzo zapośredniczony, kontakt z materią historyczną;

g) problem Petrażyckiego - eklektyzmu, klas adekwatnych; badacz dążący do wszechstronnego oświetlania badanego przełomowego momentu w dziejach miota się między dążeniem do zupełności opisu i wyjaśniania a niespójnością pojęciową czy teoretyczną. Nie może korzystać z wszystkich dostępnych na rynku badawczym paradygmatów czy dorobku teoretycznego. Chcąc zachować uporządkowany i spójny wywód i wyjaśnienie danego zjawiska, powinien odwoływać się konsekwentnie do wybranej koncepcji badawczej tak na poziomie wizji człowieka i społeczeństwa, jak i założeń epistemologicznych i zakładanej metodologii badania. Ograniczenia czynią mistrza.

Na poziomie ogólnej koncepcji społeczeństwa, koniecznej do analizy jego zmiany, badacz ma do wyboru albo organiczno-systemowy model społeczeństwa, albo wizję procesualną-podejście morfogenetyczne, w którym osią analizy jest dynamiczne pole społeczne ${ }^{3}$.

3 Przedstawia je P. Sztompka, Socjologia zmian społecznych, op. cit., s. 24-27. 
W sumie można wyodrębnić cztery pętle przyczynowe zmian: 1) via efekty strukturalne, 2) via zdolności podmiotów, 3) via zhumanizowaną przyrodę, 4) via zmodyfikowaną świadomość ${ }^{4}$. W mechanizmie zmian dochodzi zatem do połączenia globalnych efektów niewidzialnej ręki i racjonalnej kontroli instytucji państwa. W tej perspektywie dzieje cywilizacji to stopniowe podporządkowywanie środowiska przyrodniczego potrzebom ludzkiej egzystencji i rosnące zabezpieczanie społeczeństwa ludzkiego przed zagrożeniami naturalnymi, jak obecnie zmiany klimatu. W odniesieniu do świadomości wzrost ludzkiej wiedzy oznacza między innymi ewoluowanie samoświadomości zjawisk społecznych, prawidłowości, mechanizmów funkcjonowania społeczeństwa (F. Marks), zmiany, które prowadzą do podważania mitów, iluzji, „fałszywej świadomości". Pozwala to w większym stopniu antycypować, planować i celowo kształtować życie społeczne, chociaż wiedzieć to nie znaczy czynić!

Na tym wysokim piętrze uogólnienia procesu dziejowego jedno jest pewne: wiedza historyczna, w postaci różnych uogólnień i informacji faktograficznych, wymaga od politologa i badacza stosunków międzynarodowych skromności. To zmaganie się ze środowiskiem przyrodniczym, za pomocą pracy uzbrojonej techniką i wykorzystywaną energią stanowi główną linię rozwojową dziejów. „Nędza zabija więcej ludzi niż bitwy”, pisał Simon N. H. Linguet. Tę treść zawiera teoretyczne pojęcie cywilizacji, i ono też leży u podstaw wyodrębniania typów społeczeństw ludzkich - przedrolniczych, rolniczych, przemysłowych. Jeśli postawimy pytanie, co zadecydowało o sukcesie ewolucyjnym hominidów i ludzi nowoczesnych anatomicznie, odpowiedź nie będzie trudna. To kreatywne umiejętności ekologicznych dostosowań, z wykorzystaniem technologicznych innowacji - niemożliwych przecież bez największego organu człowieka - niezwykłego mózgu. Dzięki niemu mogły się pojawić wytwory przemysłu olduwajskiego, technika odłupkowa, opanowanie ognia i rozwój metod polowań, kultura oryniacka w górnym paleolicie, wykorzystująca też miękkie materiały jako surowiec aż po osiadły tryb życia, dzięki uprawie zbóż i hodowli bydła. I tak dalej. I tak dalej. Jak podkreślają znani neoewolucjoniści: „,postęp technologiczny jest naczelnym czynnikiem determinującym w konstelacji globalnych trendów - w populacji, języku, strukturze społecznej i ideologii - który określa podstawowe zarysy historii człowieka" ${ }^{\prime \prime}$. Ostatni punkt zwrotny, prowadzący do nowoczesności - to rewolucja przemysłowa, wzbierająca w kilku, jak dotąd, falach. To ona dzięki zastosowaniu nowoczesnej nauki zwiększyła moce produkcyjne, zaprzęgła nowe źródła energii, stworzyła nowe materiały, zmieniając przy okazji struktury życia społecznego i strategie życiowe ludzi. Jedno się nie zmieniło: biologiczna natura człowieka, psychomózgowy potencjał człowieczeństwa. W złożonym mechanizmie ewolucji społecznej występuje kombinacja kilku czynników: presja środowiska przyrodniczego jako wyzwanie, problem i szansa. I innowacje technologiczne oraz dostosowania organizacji gospodarki i życia społecznego. Pojawia się też, zwłaszcza podkreślana przez ewolucjonistę L. Warda rola planowania i kształtowania przyszłości jako kolejna zdobycz ewolucyjna gatunku ludzkiego. Reformy, projekty rewolucyjne, strategie narodowe, choć rzadko adekwat-

4 Ibidem, s. 216.

5 G. E. Lensky, J. Lensky, Human Societies: An Introduction to Macrosociology, New York 1974, s. 110. Cyt. za: P. Sztompka, Socjologia zmian społecznych, op. cit., s. 121. 
ne, współkształtowały konkretne alternatywy rozwojowe poszczególnych wspólnot ludzkich. Tak więc dopiero kombinacja czynników ekologicznych, technologicznych, gospodarczych, politycznych i kulturowych, z dodatkiem konkretnych okoliczności historycznych - tworzy mechanizm dynamiki dziejowej. Jak pisze I. Tattersall: ,nieodparte siły o charakterze społecznym i gospodarczym często są wynikiem różnych presji środowiska pozostających poza wszelką kontrolą społeczeństw i ich przywódców. A więc ostatecznie to czynniki zewnętrzne, niezależnie od pojedynczych ludzi, a nawet całych społeczeństw i narodów, są w istotnym stopniu odpowiedzialne za rozkwit, załamania i konflikty, a wszystkie składają się na złożoną i bogatą historię ludzkości"’6.

Rolę techniki i gospodarki umieszcza na pierwszym planie przyczynowości społecznej także J. Steward. Dopiero na dalszym miejscu plasuje państwo i politykę, ideologii zaś rezerwuje podrzędną, pochodną rolę ${ }^{7}$ Wyjaśnianie nie jest możliwe tylko przez odwołanie do czynników psychologicznych, jakoby właściwych ludziom przez całe dzieje, we wszystkich epokach. Taki charakter ma teoremat I. Morrisa, jak go autor sam nazywa: ,zmiany wywołują leniwi, chciwi i z poczuciem zagrożenia ludzie w poszukiwaniu łatwiejszych, wydajniejszych i mniej ryzykownych sposobów osiagania celów. I rzadko wiedzą, co osiagną" ${ }^{8}$. Lenistwo może powodować dążenie do ekonomii wysiłku, osiągania danych efektów jak najmniejszym nakładem wysiłku fizycznego czy umysłowego. Chciwość byłaby tym motywem, który wszedł do refleksji nad ludzkim działaniem za sprawą moralistów i ekonomistów zwłaszcza szkockiego oświecenia, głównie A. Smitha - to egoizm, który prowadzi do połączenia działań jednostek dążących do zaspokojenia swoich potrzeb, głównie bogactwa materialnego. Natomiast trzeci motyw odnosi się do bezpiecznej egzystencji (być może najpierw oddalenia bezpośrednich zagrożeń, jakie może przynieść anarchia społeczna czy wojna, okupacja własnego terytorium, wtedy bowiem życie i majątek uprzywilejowanych bywa wystawiony na większe niebezpieczeństwo). Po drugie może chodzić o życie codzienne wolne od deprywacji i uzależnienia od innych ludzi, zwłaszcza rządu. Jeśli takie bywają motywy ludzkich działań jednostkowych i zbiorowych, to jako biologiczne constans niewiele tłumaczą nam z tych przełomowych momentów historii. Dlatego większy ciężar teoretyczny ma inne twierdzenie autora: „biologia i socjologia dostarczają ogólnych praw, stosujących się do wszystkich ludzi i wszystkich czasów i wszystkich społeczeństw, geografia wyjaśnia różnice" . Jest to dość lekkomyślny pogląd. Nauki społeczne i biologiczne mają bowiem za przedmiot badania zjawiska o charakterze rozwojowym. Tworzą one w następstwie odmienne jakościowo epoki, struktury, mechanizmy determinacji. Gdyby socjolog szukał wspólnych cech wszystkich dotychczasowych społeczeństw, musiałby je redukować do takich, które występują w najprostszej postaci jak u ludów San, żyjących na skraju Kalahari. Tak myśląc jak autor, Th. Malthus sformułował prognozę dotyczącą związku między wielkością populacji a możliwościami

${ }^{6}$ P. Sztompka, Dzieje człowieka od jego poczatków do IV tysiąclecia p.n.e., Warszawa 2010, s. 167; H. H. Lamb, Climate, History and the Modern World, New York 1995.

7 J. H. Steward, Theory of Culture Change, Urbana 1979, s. 37.

8 I. Morris, Why the West Rules - For Now. The Patterns of History and What They Reveal about the Future, London 2010, s. 28 („Change is caused by lazy, greendy, frightened people looking for easier, more profitable, and safer ways to do things. And they rarely know what they're doing").

9 Ibidem, s. 557. 
jej wyżywienia przez rolnictwo „na podstawie całej naszej wiedzy o możliwościach Ziemi”. Wszystko zmieniła rewolucja przemysłowa: i w rolnictwie, i w zachowaniach prokreacyjnych mieszkańców miast, swoje zrobiły też postępy przemysłu farmaceutycznego. Słowem, biologia i socjologia operują innym typem ogólności praw, ich zakresem jest ogół epok, ogół typów społeczeństw, formują one co najwyżej prawidłowości ramowe. Do nich trzeba dodać historyczne warunki ich zachodzenia. Piszę o tym szerzej w innym miejscu ${ }^{10}$. Czasami mogą to być warunki geograficzne, ale również konflikty klasowe, nieefektywna gospodarka czy przeciwnie nadprodukcja w wyniku włączenia się do konkurencji międzynarodowej gospodarek społeczeństw nowouprzemysłowionych. Trzecia teza autora brzmi: geografia warunkuje rozwój społeczny, ale zarazem rozwój społeczny określa sposoby tego warunkowania. Myśl potwierdzona wielokrotnie, gdyż różne cechy środowiska i jego zasoby zaczynają pełnić nową rolę, wraz z pojawiającymi się wskutek rozwoju techniki szansami ich wykorzystania. Na przykład potwierdzają tę prawidłowość nowożytne dzieje Anglii: najpierw peryferyjne, na dodatek wyspiarskie, położenie na północnym krańcu Europy upośledzało jej rozwój społeczno-gospodarczy. Natomiast kiedy pojawiły się nowe możliwości żeglugi po oceanach, wtedy łatwy dostęp do Atlantyku ułatwił ekspansję kolonialną. Jednym z jej następstw był szybki rozwój gospodarczy w nowych formach organizacyjnych: kompanie, giełda, handel dalekosiężny, później rewolucja przemysłowa. Czwarta teza tej mini teorii rozwoju społecznego dotyczy bezpośrednich przyczyn przełomowych zmian: czterej jeźdźcy Apokalipsy, powodujących gwałtowne i szybkie zmiany społeczne to: zmiana klimatu, głód, upadek państwa, migracje; prowadzą one - często współwystępując - do załamania się dotychczasowego porządku, i upadku, przerwania ciągłości ładu instytucjonalnego, zejścia ze sceny historycznej - cywilizacji, narodu, imperium... Teza piąta, zarazem ostatnia, mówi o roli zacofania cywilizacyjnego. Pozwala ono - paradoksalnie - zrobić lepszy użytek z osiaggnięć pionierów, gdyż stwarza szanse udoskonalenia rozwiązań oryginalnych, uniknięcia błędów i rozwinięcia początkowej idei czy innowacji.

Ogromny dorobek mistrzów nauk społecznych może stać się strukturą heurystyczną badań, wykraczających poza pierwotne zadania, pytania badawcze i formułowane tezy czy uogólnienia. Warunkiem jest ich rozbudowa, konkretyzacja przez odniesienie do nowych zadań badawczych, nowych fenomenów i procesów, słowem, korespondencja uogólniająca między dotychczasowym zastosowaniem a nowymi potrzebami poznawczymi. Świadome wykorzystanie dorobku klasyków w danej dyscyplinie czy dyscyplinach S. Kozyr-Kowalski nazywa neoklasycyzmem i w swojej praktyce badawczej pokazał, jak go wykorzystać do wyjaśnienia różnorodnych stosunków własnościowych, występujących w nowoczesnej rynkowo-kapitalistycznej gospodarce $^{11}$. Ogólnie procedura polega na traktowaniu wyjściowych teorii bądź jako uproszczonego obrazu rzeczywistości (interpretacja realistyczna), bądź jako źródło dyrektyw metodologicznych badania, a więc na sposób instrumentalny ${ }^{12}$. Teoria wówczas

10 T. Klementewicz, Rozumienie polityki. Zarys metodologii nauki o polityce, Warszawa 2011, s. $251-257$.

11 Ibidem, s. 27-35.

12 O procedurze sterowania badaniami za pomocą teorii zob.: J. Topolski, Teoria wiedzy historycznej, Poznań 1983, s. 180-188. 
jedynie pomaga w hipotetycznej selekcji i hierarchizacji czynników wyjaśniających, wskazując te, którym należy się bliżej przyjrzeć w procesie badawczym. W naszym przypadku poszukujemy teorii scalających różnorodne mechanizmy i czynniki trwania i zmiany społeczeństw i cywilizacji lokalnych oraz oddziaływań i wzajemnej wymiany dorobku. Jednak wszystkie teorie wymagają uprzedniej konkretyzacji, tj. dostosowania do badania jednostkowego procesu historycznego, jaki jest proces powstawania cywilizacji światowej. Rzadko kiedy można bowiem odwołać się wprost do twierdzeń teorii ogólnych w procesie uzasadniania faktów szczegółowych czy prawidłowości stwierdzanych w badanym procesie. Np. oddziaływanie warunków przyrodniczych jest zapośredniczone rozwojem społecznym (atlantyckie położenie Hiszpanii, Portugalii i Anglii w czasach, kiedy technologicznie możliwe było opanowanie żeglugi oceanicznej).

Po rekonstrukcji założeń filozoficznych, dotyczących przyjmowanych wizji człowieka i świata społecznego, trzeba odtworzyć główne kategorie i tezy, a następnie przyjrzeć się sposobom posługiwania się tymi kategoriami i tezami w procesie stawiania i rozwiązywania określonych problemów badawczych. Najważniejszą fazą postępowania badawczego jest odnoszenie aparatu analitycznego danej szkoły czy jej przedstawiciela do zjawisk i procesów współczesnych, siłą rzeczy nie objętych wprost przyjętą koncepcją. Wymaga to przekształcenia oryginalnych kategorii i tez - zwiększenia bądź zmniejszenia zakresu ich niepustospełnienia: zmiany pojęcia, zakresu tezy, sformułowania teorii, modyfikacji dotychczas uznanych za trafne teorii empiryczno-historycznych (idiograficznych). Jak pisze S. Kozyr-Kowalski: z klasykami „,mamy wspólny punkt wyjścia. Ale w pewnym momencie wkraczamy na inne i nowe drogi. Korzystamy z odkrytych przez klasyków kontynentów wiedzy i narzędzi poznania, ale tylko po to, aby poszukiwać za pomocą nowych narzędzi nieznanych im lądów"13. Zawsze jednak musimy zrekonstruować strukturę dorobku szkoły: jej założenia ontologiczne, język, teorie ogólne i idiograficzne, powstałe na jej gruncie oraz postulowane doktryny praktyczne. W danym przypadku chodzi o struktury wiedzy o systemie światowym.

Najogólniejsza spośród nauk społecznych, czyli socjologia oferuje pozostałym badaczom poszczególnych podstruktur życia społecznego (ekonomistom, politologom, religioznawcom itd.) teorie społeczeństwa jako całości dynamicznej. Jako dyscyplina wieloparadygmatyczna - tak zreszta jak i pozostałe - ma w swoim repertuarze bogata ofertę. Jednak wszystkie one dotyczą społeczeństw - narodów, jak się dotąd mówiło: społeczeństw globalnych. Głównie chodzi tu o teorie społeczeństwa przemysłowego bądź kapitalistycznego (antropologia kulturowa zarezerwowała dla siebie wiedzę o społeczeństwach tradycyjnych) oraz teorie czy wizje dynamiki historycznej. Brak natomiast teorii tej największej struktury życia społecznego, jakąjest cywilizacja światowa. Nie znaczy to jednak, że w ogromnym dorobku światowej socjologii, i szerzej - nauk społecznych, nie znajdziemy dojrzałych koncepcji teoretycznych, co więcej urzeczywistnionych w praktyce badawczej. Wprost warunki takie spełnia teoria systemów-światów I. Wallersteina czy jego poniekąd mistrza i rywala - F. Braudela. Do przedsięwzięć badawczych o takich rozległych przestrzennie i czasowo ambicjach na-

13 J. Topolski, Socjologia, społeczeństwo obywatelskie i państwo, Poznań 2000, s. 33. 
leżą niewątpliwie systemy teoretyczne, wraz z próbami egzemplifikacji K. Marksa czy M. Webera. Próbę ogarnięcia czynników sprawczych zmiany społecznej, rozciągniętej na całe dzieje ludzkich społeczeństw, podjęli np. ewolucjoniści i neoewolucjoniści. Natomiast faktograficznej rekonstrukcji procesu dziejowego splatania się losów, leżących na mapie daleko od siebie, dokonują historycy świata (world history), antropogeografowie, antropolodzy kulturowi, szukający uwarunkowań i mechanizmów rozwoju, zastoju, upadku wielu społeczeństw, cywilizacji lokalnych, odmiennych ścieżek rozwojowych ludów zamieszkujących różne habitaty. We własnej dyscyplinie politolog ma do rozpatrzenia kierunki i szkoły badawcze, próbujące ogarnąć analitycznie historyczne i współczesne formy stosunków międzynarodowych (J. N. Rosenau, R. Gilpin, S. D. Krasner, H. Bull).

Schemat 1. Relacje między globalnym ekosystemem, działalnością gospodarczą ludzkości, globalnym rządzeniem i kulturą

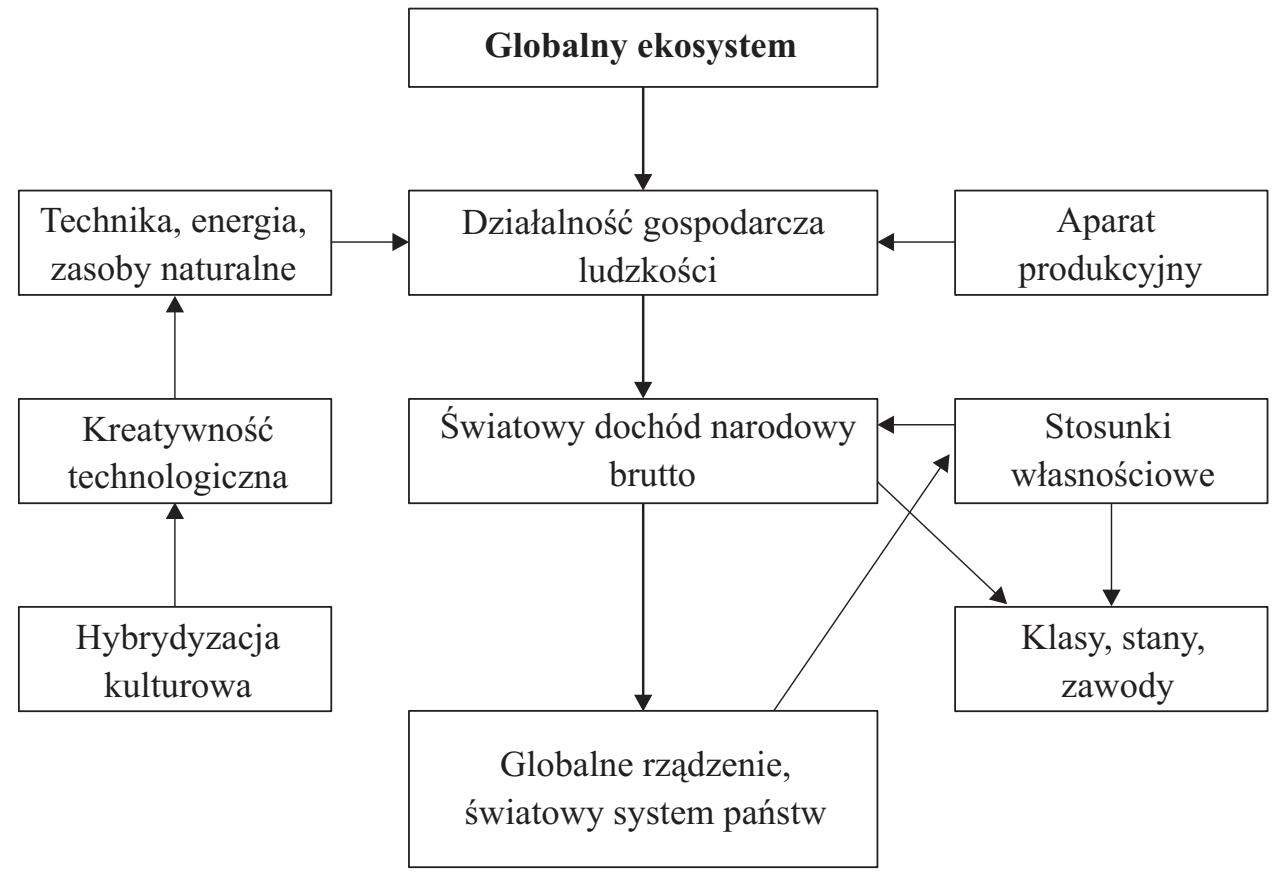

Źródło: Opracowanie własne.

Poszukujemy zatem takich koncepcji teoretycznych, które w miarę spójnie łączą nie tylko poziomy funkcjonowania cywilizacji światowej (ujęcie relacyjno-strukturalne, zob. schemat 1). Chodzi też o wskazanie czynników zmiany (ujęcie procesualno-dynamiczne), z uwzględnieniem jakościowych różnic między typami gospodarki, techniki, społeczeństwa, kultury. A wśród czynników trwałości i zmiany różnych struktur dostrzegać zjawiska i procesy przeciwstawne i sprzeczne, bliskie faktycznej złożoności związków i uwarunkowań między różnymi elementami całości społecznych i przyrodniczo-społecznych. Ale to nie wszystko. Ważną rzeczą jest też sprowadzanie 
wszystkich struktur życia społecznego do zbiorowych i jednostkowych działań ludzi, do ich kreatywności przy przezwyciężaniu strukturalnych ograniczeń. Wychodzi temu naprzeciw teoria stawania się społeczeństwa P. Sztompki czy koncepcja morfogenezy M. Archer. Na gruncie politologii taki program badania obecnej fazy globalizacji sformułowała B. Krauz-Mozer. Wskazuje ona, że ,pytanie, na które nauki polityczne powinny przede wszystkim poszukiwać obecnie odpowiedzi, dotyczy przyszłości - w jakim stopniu może ona być kontrolowana przez aktywne jej tworzenie, a co, ile i w jakim stopniu może zależeć od zastanych albo już utrwalonych struktur"14. Trafnie upatruje w dyskursach i utrwalanych medialnie ideach - częściowo za M. Archer - pośredniczącej roli między strukturą a podmiotowością jednostek. Mianowicie, pełnią one rolę swoistego ,filtra kulturowego”, a największym takim filtrem jest panująca do niedawna nad umysłami współczesnych ortodoksja neoliberalna, dodajmy od siebie.

Zgodnie z dotychczasowymi rozważaniami struktura wiedzy o cywilizacji światowej przedstawia się następująco :

1) wiedza o miejscu biosfery w systemie Ziemi i roli populacji ludzkiej w globalnym ekosystemie - dane o metabolizmie społecznym; związki gospodarki i przyrody (uwarunkowania przyrodnicze i techniczne rozwoju społecznego). nauka o Ziemi jako systemie, ekologia systemów, ekologia populacyjna, ekologia człowieka;

2) systemowa koncepcja człowieka jako wytworu antropogenezy i antropoewolucji wg psychologii ewolucyjnej, antropologia fizyczna;

3) dzieje populacji homo sapiens, genetyka populacyjna, demografia historyczna (R. Malthus, L. Cavalii Sforza);

4) ekonomia gospodarki narodowej (produkcji, cyrkulacji, podziału produktów...) oraz teorie cyrkulacji kapitału, handlu, łańcuchów produkcyjnych, migracji siły roboczej, roli metropolii; teorie waloryzacji i akumulacji kapitału w skali wszystkich gospodarek narodowych; teorie historycznych faz rozwoju gospodarki kapitalistycznej (cykli, kryzysów, ładów produkcyjnych - teorie empiryczno-historyczne, idiograficzne);

5) teoria operacyjnych i systemowych funkcji państw, teoria globalnego rządzenia, teorie polityki międzynarodowej (K. Waltz);

6) teoria hybrydyzacji kultury (U. Hannertz); teoria komunikacji międzynarodowej, międzykulturowej;

7) koncepcje łączące podstawowe poziomy funkcjonowania społeczeństw: teorie ogólne (programy badawcze) łączące wszystkie poziomy analizy: F. Braudela koncepcja historii totalnej (globalnej), teoria systemu światowego I. Wallersteina, warstwa sterująca rekonstrukcją dziejów dokonaną przez historyków (np. I. Morris); wpływ uwarunkowań przyrodniczych (J. Diamond, A. Crosby).

U każdego klasyka trzeba rozwijać brakujące ogniwa albo dołączać je od innych koncepcji. Np. Marks nie rozwinął, z braku ówczesnej wiedzy (do rozporządzenia była tylko książka Morgana), wątku dotyczącego uwarunkowań przyrodniczych i finansowej natury kapitalizmu; F. Braudel unikał definicji, jego koncepcja właściwie została

14 J. Topolski, Globalizacja - metodologiczny problem politologii, w: Globalizacja-nieznośne podobieństwo? Świat i jego instytucje w procesie uniformizacji, red. B. Krauz-Mozer, Kraków 2008 , s. 74. 
zastosowana do opisu systemu Śródziemnomorza (przecież nie mniej nasycone więzi gospodarcze, militarne, kulturowe występowały między państwami, imperiami w Zachodnim basenie Oceanu Indyjskiego (ścierały się tutaj migracje ludów sinotybetańskich z wpływem kultury indyjskiej, zwłaszcza buddyzmu).

Rozpowszechnione w naukach społecznych całościowe wizje dynamiki historycznej obejmują czynniki trwania/rozwoju społeczeństw narodowych (np. strukturalny funkcjonalizm Parsonsa). Przed wyborem najbardziej obiecującej heurystycznie koncepcji, dokonajmy wstępnej selekcji (swoistego castingu). Do zrozumienia współczesności, zwanej nowoczesnością, i dla oceny roli różnych czynników sprawczych zmiany społecznej zauważmy:

- trzeba rozróżnić procesy względnie autonomiczne: industrializację (związaną pośrednio z rewolucja naukowa, pojawieniem się fabryki, silnika parowego, później spalinowego i elektryczności). Tłumaczy ona skokowy wzrost produktywności pracy dzięki nowym źródłom energii i nowej organizacji pracy ludzkiej. Jest to więc sfera technologii- domena ewolucjonizmu i cywilizacji. Tendencje te uogólnia teoria społeczeństwa przemysłowego i nowoczesności: Saint-Simon, Weber, Durkheim, Simmel, Toennies, Tocqueville, Dahrendorff;

- następnie trzeba odróżniać proces powstawania kapitalistycznej gospodarki (związanej z najemną praca, konkurencją między kapitałami, prowadzącą do „twórczego burzenia" i dążeniem do akumulacji, którą umożliwił duży wzrost masy zysków dzięki technice). To domena ekonomii politycznej i socjologii ekonomicznej (Smith, Marks, Weber, Schumpeter, Keynes, Polanyi, Wallersein). Kapitaliści zachowują się w określony sposób wobec innych ludzi (robotników) wykorzystują ich, narzucają tempo pracy, wprowadzają zasady zarządzania, które czynią pracę uciążliwą. Źródłem tego nie jest nauka, nie jest technika, lecz organizująca pracę praktyka społeczna, którą kierują cel główny, a jest nim maksymalizacja zysku. Natomiast istnieją prawidłowości kapitalistycznej gospodarki; są one całkowicie wewnętrzne, właściwe temu systemowi produkcji, podporządkowanemu prywatnej własności;

- wreszcie od nowoczesności, z którą zrośnięta jest socjologia akademicka, i która tak fascynowała pierwsze pokolenie socjologów - obecnych klasyków (Weber, Simmel, Toennies, Durkheim), i która w nie mniejszym stopniu przykuwa uwagę obecnych neoklasyków (Z. Bauman, Beck, J. Habermas czy A. Giddens). Otóż, główny nacisk w ich ujęciu spoczywa na zmianach stylu życia, rolach społecznych, niepewności egzystencji, roli wykształcenia itd. Dotyczy zatem socjopsychologicznych następstw industrializacji i rynkowego społeczeństwa. W pierwszym pokoleniu socjologów była nią racjonalność, rola więzi stowarzyszeniowych, solidarności mechanicznej itd., poza oczywiście próbą ogarnięcia całego organizmu społecznego. Ten poziom analizy rynkowego społeczeństwa to domena szeroko rozumianej kultury i świadomości społecznej. Składają się na nią: równość szans i awansu, prawa obywatelskie, demokracja przedstawicielska, kontrola konfliktu przemysłowego, etos, systemy wartości, mentalność, typ rodziny, gromadzenia wiedzy, religii (Beck, Z. Bauman, A. Giddens), antropologia globalna (A. Appadurai, W. Burszta, J. Clifford).

Decydujący był, moim zdaniem, przewrót techniczny XIX wieku i szerokie zmiany społeczne, kulturowe, polityczne, które przyniósł: industrializację, urbanizację, demokratyzację, powstanie nowoczesnych narodów i państwa demokratyczno-liberalnego. 
W szczególności trzeba poznać następujące relacje:

- między przyrodą a gospodarką (metabolizm społeczny): praca, energia, technika - typy społeczeństw (myśliwsko-zbierackie, agrarne, przemysłowe). To perspektywa ewolucjonizmu - innowacyjności, technologii, kreatywności, dialektyki struktur i działania. Do wykorzystania na gruncie strategii neoklasycyzmu jest też koncepcja czynników zmiany i cykli gospodarczych Marksa, Schumpetera, Keynesa. Perspektywa marksowska obejmuje przede wszystkim społeczną organizację procesu produkcji oraz stosunki własnościowe;

- między gospodarką a państwem, ukazać ponadto jego operacyjne, a zwłaszcza systemowe funkcje; w tym też współdziałanie na szczeblu ponadnarodowym. Główne pytanie dla politologa to pytanie, kto wykorzystuje instrumentarium państwa, tj. kto jest głównym beneficjentem jego interwencji w obrębie społeczeństwa narodowego i w jego relacjach z pozostałymi społeczeństwami.

Jako koncepcja heurystyczna, łącząca wszystkie poziomy, największymi walorami heurystycznymi odznaczają się koncepcje F. Braudela i I. Wallersteina.

\section{FERNAND BRAUDEL A KONCEPCJA HISTORII GLOBALNEJ (TOTALNEJ)}

Fernand Braudel to najwybitniejszy przedstawiciel szkoły Annalistów, pragnących przezwyciężyć słabości tradycyjnej historiografii „królów, herosów i bitew” na rzecz rekonstrukcji głębszej - w sensie uwarunkowań przyrodniczych, gospodarczych czy mentalnych - codziennej aktywności życiowej krążącej w minionych epokach i współcześnie wokół zdobywania chleba. Choć czas pracy zmniejszył się o 50\% w porównaniu z połową XIX wieku. Historyk francuski wyodrębnia trzy poziomy rzeczywistości społecznej i zarazem trójrytmiczności historycznego czasu:

- poziom historii strukturalnej, długiego trwania, długiej fali (fr. longue duree). Pisze F. Braudel: „zaczynaj od mapy” „przestrzeń jako punkt wyjściowy rozważań włącza w grę równocześnie wszystkie realia historii, wszystkich użytkowników obszaru: państwa, społeczeństwa, kultury, gospodarki..."15. Tworzy ją środowisko przyrodnicze, często przez tysiąclecia ograniczające pole alternatyw gospodarowania jak w tropikach. Dalej, biologiczna natura człowieka, określona przez pulę genową danej populacji; np. stopa urodzeń, przeciętne trwanie życia ludzkiego w danych epokach i typach społeczeństw. Kolejnym elementem są wymogi życia duchowego, np. myślenie religijne, związane $\mathrm{z}$ lękiem przed śmiercią, czy magiczne korespondujące z nikłymi technologicznymi środkami kontroli przyrody czy brakiem kontroli nad tym, co przynosi fortuna. Historia strukturalna określa granice i szanse ludzkiej aktywności; działanie jednostek nawet największych nie może iść pod prąd jej naciskom i ograniczeniom; czas długi jest najważniejszy, trzyma jednostkę na uwięzi; jej rytm jest najdłuższy, nawet milenijny;

15 J. Topolski, Kultura materialna, gospodarka i kapitalizm XV-XVIII wiek, t. III, Warszawa 1992, s. 11. 
- drugi poziom to historia koniunkturalna, obejmująca analizę rzeczywistości gospodarczej (trendy sekularne, cykle Kondratiewa i Junglara), politycznej (czas rządów np. szlachty czy magnaterii w II Rzeczpospolitej, teraz opozycji demokratycznej z lat siedemdziesiątych ubiegłego wieku), kulturowej i militarnej, a także społecznej (zbiorowości i grup, np. czas wpływu politycznego junkrów pruskich). W rzeczywistości politycznej, by sięgnąć do różnych autorów przykładem byłyby: fale demokratyzacji S. Huntingtona (1828-1926; 1943-62; 1972 ...), cykle hegemonialne P. Kennedy'ego (hegemonia Hiszpanii, Holandii, Anglii i USA, skorelowana z przewagą gospodarcza). Różne są źródła falowania aktywności w cyklach koniunkturalnych: dla cykli demograficznych początkiem może być wzrost poziomu życia; w cyklach gospodarczych wielkie innowacje ekonomiczne; w życiu politycznym może to być czas panowania politycznego, popularność programów i/lub ekip przywódczych, zużywanie się technologii rządzenia. Trwają one na ogół kilka, kilkanaście lat, liczmy je zatem za pomocą kalendarza;

- historia wydarzeniowa, historia ludzi, ich działań, będąca przejawem gry i walki politycznej. Obfituje ona każdego dnia nowymi decyzjami, spektaklami poparcia, konferencjami, pojedynkami herosów sceny politycznej. Jak pisze F. Braudel, to „fale unoszone potężnym ruchem przypływów i odpływów życia materialnego”. Toczy się ona w rytmie zegara i kalendarza.

Interesuje go proces kontynuacji (reprodukowania się złożonego systemu gospodarki świata śródziemnomorskiego), dokonujący się postęp i zmiany jakościowe (rozwój), ale też cykle, nawroty, stagnacja i regres, słowem - dyskontynuacja i zmiana.

Swoją koncepcję zastosował do analizy dziejów społeczeństw, państw i ludzi, tworzących system powiązanych oddziaływań w obrębie Morza Śródziemnego w przedziale od wieku XIII do XVIII. W tym okresie dokonała się wielka transformacja społeczna: od gospodarki począwszy na kulturze skończywszy. Dlatego bada codzienną aktywność odbywającą się głównie na rynkach miast i w warsztatach rzemieślniczych, później manufakturach, a wreszcie w fabrykach; bada produkcję i wymianę na rynkach narodowych, i w końcu - międzynarodowe przepływy towarów - handlu lokalnego i dalekosiężnego. Węzłami tego handlu stają się metropolie. „Centrum, 'serce', gromadzi wszystko to, co najbardziej zaawansowane i zróżnicowane. Pierścień następny rozporządza tylko częścią owych korzyści, choć ma w nich udział: jest to strefa 'wspaniałych namiastek'. Ogromne i słabo zaludnione peryferie są natomiast zacofane, zapóźnione, z łatwością poddają się uciskowi. Owa dyskryminacyjna geografia dziś jeszcze stanowi pułapkę dziejową i zarazem wyjaśnia ogólną historię świata [...]"16. Obrazowo falowanie na trzech poziomach życia społecznego można przedstawić jak na schemacie 2.

Wbrew pozorom F. Braudel stronił od przyjęcia jakiej koncepcji teoretycznej jako układu sterującego badaniami historycznymi, w szczególności uchylał się od głośnego wówczas sporu między marksizmem a strukturalizmem. Głównie interpretował źródła, których był niedościgłym odkrywcą i znawcą oraz bogatą literaturę problemu. W jego ujęciu najważniejsza był struktura tekstu, nawet - paradoksalnie - ważniejsza od

16 Ibidem, s. 28. 
Schemat 2. Trójrytmiczność historycznego czasu F. Braudela (czas dlugiego trwania, czas koniunktur i historia wydarzeniowa)

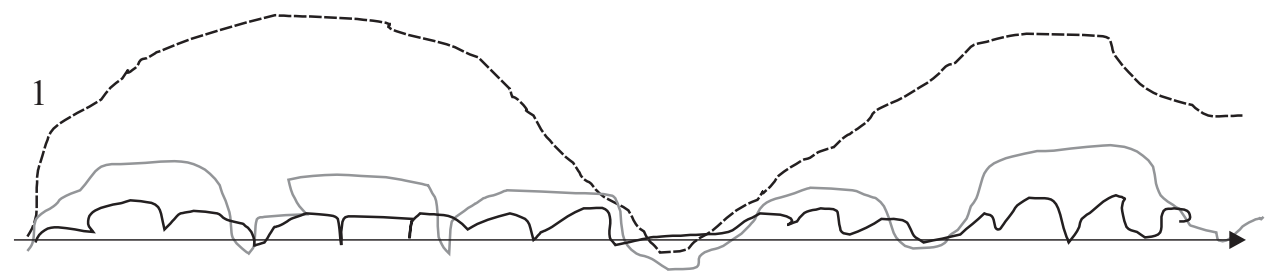

Źródło: Opracowanie własne.

zawartości rozdziału. I przede wszystkim zniewalająca walorami retorycznymi i literackimi proza. Zreszta jego metoda przypomina malowanie piórem największych prozaików - jak Sienkiewicza. Oczami wyobraźni widział na przykład znojną orkę ówczesnego chłopa i potrafił odmalować piórem - niczym impresjonista - ten obraz czytelnikowi. Słowem, jego dzieła są produktem niepowtarzalnego geniuszu i mogajedynie inspirować do konstruowania całości narracyjnych o danych procesach cząstkowych prowadzących do jednego systemu-świata ${ }^{17}$.

\section{IMMANUEL WALLERSTEIN}

Reprezentuje on nurt badania współczesności w kategoriach kapitalistycznej gospodarki-świata. Charakterystyczna dla jego ujęcia jest rezygnacja z kategorii państwa (społeczeństwa) narodowego i pojęcia rozwoju. Kojarzy się ona bowiem z potencjałem zmian tkwiącym wewnątrz danego społeczeństwa (jak sprzecznościami między siłami wytwórczymi a stosunkami produkcji czy między sposobem produkcji a nadbudową prawno-polityczną u Marksa). Kładzie natomiast nacisk na czynniki egzogenne: podbój, naśladownictwo rozwiązań płynących z zewnątrz, rywalizacji czy eksploatacji ze strony sprawniejszych firm, gospodarek, państw, tworzących historyczne całości. W przeciwieństwie do realizmu jako nurtu badawczego w nauce o stosunkach międzynarodowych zrywa on z obrazem społeczeństwa (państwa narodowego) jako izolowanego, do pewnego stopnia niezależnego, rozwijającego swój cywilizacyjny czy uzależniony od lokalnego ekosystemu- potencjał. Charakterystyczne jest zatem traktowanie odrębnego narodowego społeczeństwa jako węzła w sieci państw narodowych, ich gospodarek, atrakcyjnych kultur. Dodatkowo tego socjologa charakteryzuje perspektywa radykalna. W centrum uwagi znajduje się bowiem nie tylko rozległa makrostruktura, której elementami są narodowe systemy produkcyjne, regiony świata, a więc potraktowana

${ }^{17}$ O metodzie badawczej i koncepcji historii globalnej tego wielkiego historyka francuskiego pisało wielu autorów m.in. ostatnio Cheng-chung Lai, Braudel's Hisorigraphy Reconsidered, University Press of America 2004, s. 1-30; I. Wallerstein, Braudel on capitalism, or everything upside down, „Journal of Modern History” 1991, No. 63, s. 354-361; T. Stoianovich, French Historical Method: the Annales Paradigm, Cornell Univerity Press 1976. Pełną prezentację koncepcji metody badawczej F. Braudela zawiera też praca: A. Grabski, Koncepcja historii globalnej - Fernand Braudel, w: Ksztatty historii, Łódź 1985. 
holistycznie gospodarka światowa. Ponadto stara się on poznać mechanizmy przepływu nadwyżki ekonomicznej, prowadzące do eksploatacji regionów uzależnionych. Ten nurt badawczy zrodził się na kanwie zainteresowania powstawaniem rynku światowego, debatą nad przyczynami „,wielkiego rozwidlenia” między Wschodem a Zachodem oraz rolą zmodernizowanej, uprzemysłowionej, kapitalistycznej Europy w połączeniu odrębnych cywilizacji lokalnych w system światowy. Wśród inspiracji znajduje się wprowadzona w kręgu szkoły dependencia (zwłaszcza R. Prebisch i A. G. Frank) kategorie centrum-peryferie, powiązanych z osiowym podziałem pracy, monopolizacją przynoszących największą wartość dodaną faz produkcji w metropolii. Drugie zasilanie jest dziełem historiograficznej szkoły Annalistów, z mistrzem drugiego pokolenia - F. Braudelem. Od tego papieża współczesnej historiografii pochodzi kategoria gospodarki-świata (fr. economie-monde), zastosowane do analizy ogromnego regionu gospodarczych i kulturowych więzi, jakim był przez całe dzieje od rewolucji neolitycznej obszar Śródziemnomorza.

Właśnie analiza stosunków międzynarodowych z globalno-systemowego punktu widzenia, uznanie, że świat ma naturę systemową, a w tym systemie determinującą rolę odgrywa gospodarka, jest znakiem rozpoznawczym teorii systemu-świata I. Wallersteina $^{18}$. Rdzeń koncepcji I. Wallersteina wyrasta ze strategii badawczej K. Marksa. Główne konflikty napędzające dynamikę procesów historycznych rodzą się z odmiennego usytuowania ludzkich grup w strukturze gospodarczej różnych społeczeństw, połączonych osiowym podziałem pracy. W centrum uwagi znajduje się proces akumulacji nadwyżki ekonomicznej oraz rywalizacja o jej podział. Stąd rozwój dokonuje się drogą przezwyciężania konfliktów i sprzeczności między działającymi kolektywnymi podmiotami dziejów, przy czym nie są to - jak w tradycyjnym marksizmie odmiennie usytuowani w procesie produkcji właściciele kapitału i właściciele siły roboczej. Jednostką analizy jest system-świat, rozumiany jako światowa gospodarka, zintegrowana przez wymianę rynkową (we wcześniejszych epokach taką rolę odgrywało państwo, tworząc imperia, a jeszcze wcześniej istniały tzw. mini systemy oparte na wymianie społecznej). Jak głosi amerykański socjolog: ,,w systemach-światach mamy do czynienia z obszarem przestrzenno-czasowym, który obejmuje liczne jednostki polityczne i kulturowe i który jest jednocześnie zintegrowanym obszarem działań i instytucji podporządkowanym pewnym systemowym zasadom"19. Tak więc system światowy obejmuje różne kulturowo zróżnicowane narody, uczestniczące w podziale pracy. One są jego elementami, główną jednostką analizy jest zaś trwający w długim czasie „konkretny system historyczny". Obejmuje on produkcję i wymianę podstawowych dóbr i towarów, koniecznych do zaspokojenia potrzeb swoich mieszkańców. Analogicznie zauważmy, że Arystoteles definiował społeczeństwo jako samowystarczalną całość organiczną. Ten podział pracy prowadzi do utrzymywania się odrębnych regionów: rdzenia (centrum) i peryferii. Społeczeństwo globalne ulega hierarchizacji. Kryterium podziału jest rodzaj dóbr dostarczanych do wspólnej przestrzeni gospodarczej, czy są to produkty przetworzone, nasycone technologiami i kapitałem, czy przeciwnie - będące nośnikiem prostej, niewykwalifikowanej pracy. Władza, w tym siły militarne,

18 Por.: I. Wallerstein, Analiza systemów-światów. Wprowadzenie, Warszawa 2007.

19 Ibidem, s. 33. 
i wpływy w systemie światowym znajdują się po stronie centrum. Ono dominuje i eksploatuje ubogie peryferyjne społeczeństwa. Tak więc to poziom rozporządzalnych technologii i techniki produkcji, produktywność pracy ludzkiej jest ostatecznym czynnikiem pozycjonowania narodowych społeczeństw w hierarchii narodów, w systemie światowym. Rozwój krajów peryferyjnych, uwarunkowany jest potrzebami centrum, podlega ciagłemu przystosowaniu strukturalnemu do wymagań akumulacji kapitału, i reprodukuje podporządkowany status. Kluczową sprawą jest podział nadwyżki w skali światowej między centrum a peryferie. I. Wallenstein twierdzi, że wymiana handlowa jest nieekwiwalentna (na to też składają się niższe koszty pracy na peryferiach), zatem dokonuje się systematyczny transfer nadwyżki ze społeczeństw-proletariatów do rozwiniętego pod względem technologii, zindustrializowanego centrum. To prowadzi do akumulacji kapitału na globalną skalę, i pociagga za sobą apropriację i transformację nadwyżki z peryferii. Rodzi globalną walkę narodów-klas. Imperializm polega na dominacji centrum nad peryferiami. Hegemonia zaś powstaje wówczas, gdy jedno państwo centrum przewyższa pozostałe. Ostatecznym rezultatem procesu opanowywania globu przez zaawansowaną technologicznie, sprawną organizacyjnie, zaasekurowaną przewagą militarną, kontrolującą instytucje międzynarodowe bogatą Północ - jest powstanie jednego systemu współzależności ekonomicznych. Jednak z powodu nierównego tempa rozwoju, różnej produktywności pracy, jest on asymetryczny i wysoce nieegalitarny. Dopiero też na globalnych rynkach można rentownie lokować oszczędności i inwestycje w różnych gałęziach produkcji i rodzajach działalności gospodarczej. Duże znaczenie ma tutaj miejsce lokalizacji firmy macierzystej wielonarodowej korporacji, ponieważ tu zapadają decyzje inwestycyjne, dotyczące podziału zysku, tutaj też płyną zyski. Ma to zatem silny wpływ na światową akumulację kapitału - według określenia S. Amina ${ }^{20}$. I. Wallerstein, podobnie jak wcześniej K. Polanyi, przeciwstawia wcześniejsze epoki, kiedy gospodarcza aktywność była podporządkowana zaspokajaniu potrzeb całej zbiorowości, a jej organizację określał podział pracy według płci lub różnych totemicznych zasad (klany ideacyjne). Następne było stadium imperiów rolniczych, które mogły eksploatować - używając ostatecznie środków przemocy fizycznej - bogactwa naturalne, pobierać trybut, przyłączały ziemie uprawne, brały w niewolę siłę roboczą. Jednak nie miały środków transportu, logistyki, wojska (wobec małych nadwyżek i mniejszej populacji), żeby na dłużej opanować większą przestrzeń. Wówczas raczej asymilowały przyłączane obszary (imperium chińskie, rzymskie, perskie, kilka islamskich, np. Osmanów). Stosunki między centrum a peryferiami utrzymywano dzięki sile polityczno-militarnej. Zdaniem amerykańskiego socjologa, nowoczesny system światowy powstał dopiero wraz z rozwijającym się, zapoczątkowanym w XVI i XVII wieku kapitalizmem. Dopiero wówczas procesy gospodarcze: wymiana handlowa, w tym handel niewolniczy, inwestowanie kapitału w różnych rejonach świata, organizowanie produkcji towarów kolonialnych daleko od macierzystych metropolii - stworzyło globalny system, oparty na wymianie rynkowej, wspieranej na początku działami karaweli, ostrzeliwaniem nabrzeży niechętnych wolnemu handlowi

20 I. Wallerstein, Accumulation on the World Scale, New York 1971, s. 289. Np. jak podaje A. Giddens $45 \%$ największych firm produkcyjnych w Meksyku należało jeszcze przed powstaniem NAFTA do zagranicznych właścicieli. A. Giddens, Socjologia, Warszawa 1998, s. 166. 
(czytaj: free trade imperialism). Władza polityczna zaś skupiała się w aparacie państw narodowych, które rozparcelowały przestrzeń geograficzną na macierz i kolonie, oddzielając je granicami. Jednak gospodarka kapitalistyczna działa na obszarze większym niż mogący znaleźć się pod całkowitą kontroląjakiegokolwiek państwa narodowego ${ }^{21}$. Ważnym teoriopoznawczym i metodologicznym wnioskiem tej analizy rzeczywistości społecznej w skali globu ziemskiego jest przyjęcie jednolitej ramy analitycznej, z centralną kategorią systemu-świata. Analiza tej całości społecznej wymaga przekroczenia opłotków zarezerwowanych dotychczas dla nauk społecznych: ekonomii, politologii i socjologii. Strategię zintegrowanego badania systemu światowego nazywa I. Wallerstein „strategią unidyscyplinarną”, a zespolone na ich gruncie analizy „historycznymi naukami społecznymi". Jej stosowanie prowadzi też do przezwyciężenia dychotomii idiografizm-nomotetyzm w ujmowaniu zjawisk społecznych. Pisze bowiem, że ,systemy historyczne, w których żyjemy są na równi - w samej rzeczy - systemowe i historyczne" ${ }^{, 22}$. Także problem kwantyfikacji znajduje tu właściwe rozwiązanie przez odrzucenie techniko-centryzmu. Jak pisze autor: „zagubionego klucza nie należy szukać pod latarnią tylko dlatego, że jest tam jaśniej (czyli tam, gdzie łatwiej o dane w większym stopniu poddające się kwantyfikacji)" ${ }^{\prime 23}$.

Ale ujęcie amerykańskiego badacza ma też słabości. Należą do nich: 1) niedocenianie konfliktów wewnętrznych; 2) nie doceniał też siły państw narodowych, ich skumulowanych sił militarnych; 3) powstanie konkurencyjnych centrów produkcji przemysłowej i innowacji (Chiny, nowo uprzemysłowione gospodarki azjatyckie oraz Indie, Brazylia, Turcja, Indonezja) zmieniło światowy system-gospodarkę. W następstwie konkurencji państw rozwojowych mamy jednocześnie do czynienia ze światową nadprodukcją i podkonsumpcją; 4) budzi wątpliwości również jego odpowiedź na pytanie, kiedy Zachód uzyskał przewagę? I. Wallerstein widzi cezurę w długim XVI wieku, A. G. Frank w wieku XIX, F. Braudel zaś już w XIII wieku. Ogólnie biorąc, w gospodarkach przedkapitalistycznych stagnacja była wynikiem czynników zewnętrznych, takich jak wojny, zaraza, spadek liczby ludności czy katastrofy naturalne. Czynniki takie występują nadal, ale podobnie jak u K. Marksa i Keynesa, kapitalizm wytwarza endogeniczne albo skierowane przeciwko sobie zmiany porządku ${ }^{24}$.

Na gruncie neoklasycznej ekonomii rozwinęła się szkoła czy paradygmat badawczy zwany liberalizmem, liberalizmem instytucjonalnym. W myśl tego paradygmatu stosunki między społeczeństwami narodowymi ewoluują w kierunku większego dobro-

21 I. Wallerstein, The Modern World System, New York 1974, s. 348. Tak samo ten proces charakteryzował Marks pisząc, że ,potrzeba coraz szerszego zbytu dla swych produktów gna burżuazję po całej kuli ziemskiej. Wszędzie musi się ona zagnieździć wszędzie zadomowić, zadzierzgnąć stosunki. Przez eksploatację rynku światowego burżuazja nadała produkcji i konsumpcji wszystkich krajów charakter kosmopolityczny. Ku wielkiemu żalowi reakcjonistów usunęła spod nóg przemysłu grunt narodowy [...] dawna lokalna i narodowa samowystarczalność i odosobnienie ustępują miejsca wszechstronnym stosunkom wzajemnym i wszechstronnej współzależności narodów. I to zarówno w produkcji materialnej, jak i produkcji duchowej”. K. Marks, F. Engels, Pisma zebrane, Warszawa 1979, s. 356-358.

${ }^{22}$ I. Wallerstein, Analiza systemów światów, op. cit., s. 36.

23 Ibidem, s. 37.

24 G. Ingham, Kapitalizm, Warszawa 2011, s. 145. 
bytu, większej wolności oraz rosnącej harmonizacji interesów między kolektywnymi uczestnikami, jakimi są państwa-instytucje. Jako racjonalni aktorzy działają one w anarchicznym środowisku międzynarodowym w zgodzie ze swym egoistycznym interesem narodowym, ale dążą do możliwego do osiągnięcia wspólnego interesu. Jest nim wzrost korzyści ze współpracy o charakterze absolutnym. Główna do tego droga wiedzie przez intensyfikację wymiany handlowej. Wolny handel prowadzi bowiem do współzależności, która jest główną przyczyną pokoju. Jeśli wymiana handlowa spaja więzami wszystkie strony, rosną koszty wojen. Miarą tej współzależności są koszty zerwania współpracy, i odwołanie się do przymusu czy siły militarnej. Np. są one większe dla importera ropy naftowej, niż importera dóbr luksusowych. Ważną kategorią tego podejścia jest kompleksowa współzależność (ang. complex interdependence). Zakłócenie ładu, opartego na wymianie staje się nieopłacalne dla wszystkich uczestników. Wzmacnia to zatem dążenie do rozwiązywania konfliktów na drodze pokojowej, z pierwszeństwem dla negocjacji i poszukiwania wspólnych korzyści. Dla współczesnych uczestników wymiany handlowej według reguł WTO, powrót do nacjonalizmu ekonomicznego, protekcjonizmu niósłby ze sobą duże koszty ekonomiczne - i dlatego ten fakt determinuje politykę międzynarodową poszczególnych państw. Przesłanki tej koncepcji pochodzą z klasycznej ekonomii A. Smitha. W tej koncepcji skłonność do wymiany (handlu) jest jednym z elementów konstytuujących naturę ludzka. Wynika też z potrzeb społecznych, dyktowanych podziałem pracy i posiadanymi zasobami. Zasada niewidzialnej ręki rynku przeniesiona jest tu na poziom międzynarodowy. Liberalizm w relacjach między społeczeństwami narodowymi nie zakłada, że struktura rynku zawsze generuje bodźce do współpracy. Twierdzi jedynie, że struktura rynku może wytwarzać bodźce do „postaw cechujących się bądź to otwartością, bądź też rezerwą ${ }^{25}$. Przy takim założeniu współpraca międzynarodowa, zwłaszcza wymiana handlowa, staje się jednym z czynników kształtujących strategię działania państw w systemie międzynarodowym. Maksymalizują one swoje korzyści, zwiększając absolutne zyski z kooperacji z innymi państwami. Dobrami wspólnymi są dla liberałów: konkurencja, wolny rynek, wzrost gospodarczy, maksymalizacja renty z kapitału, wydajność, innowacyjność, uzyskanie przewagi porównawczej czy większej produktywności pracy. Osiaggają wspólne cele dzięki wzajemnym dostosowaniom, kalkulacjom, odwzajemnianiem korzyści i przysług. Współpracy tej może zagrażać jedynie nieprzestrzeganie porozumień i oszustwa, oportunizm (jazda na gapę). Co jednak się dzieje, kiedy dochodzi do konfliktu egoistycznych interesów państw, zwłaszcza konfliktów handlowych? Tu pojawia się rola reżimów międzynarodowych - prawa międzynarodowego, międzynarodowych instytucji, głównie chodzi o porozumienie o wolnym handlu i koordynującą rolę WTO, organizacji pozarządowych, ruchów społecznych, korporacji ponadnarodowych. Jednak państwa narodowe pozostają nadal

25 A. Moravcsik, O roli preferencji: liberalna teoria polityki międzynarodowej, „Res Publika Nowa” 2004, nr 3; J. Czaputowicz, Teorie stosunków międzynarodowych. Krytyka i systematyzacja, Warszawa 2007; A. Budnikowski, Międzynarodowe stosunki gospodarcze, Warszawa 2006, s. 36-40; A.-M. Slaughter, Liberal International Relations Theory and International Economy Law, $\mathrm{w}$ : The Impact of International Law on International Cooperation, eds. E. Benvenisti, M. Hirsch, http://www.princeton.edu/ slaugter/SlaughterCV2.pdf. 
głównymi aktorami stosunków międzynarodowych. Wypracowanie tych zasad ułatwia zaspokajanie potrzeb coraz większej grupy podmiotów - państw narodowych, organizacji pozarządowych, korporacji itd. W sumie - reżimy międzynarodowe i instytucje pełnią rolę „,pośrednika”. W tym miejscu pojawia się koncepcja globalnego rządzenia. Ułatwia ono współpracę narodów. Bardziej szczegółowe opracowanie tej koncepcji znane jest jako liberalny instytucjonalizm, czyli neoliberalizm. W kanonicznej postaci istnieje w pracach J. Ney'a jr i R. Keohane'a ${ }^{26}$. Jeśli chodzi o wolny handel, to głównym problemem stała się polityka celna, stosowanie ceł ochronnych. Pierwszy przemówił w tej sprawie w interesie rozpoczynających drogę do uprzemysłowienia Niemiec Georg F. List. Jego zdaniem - wbrew poglądom A. Smitha - wolny handel był pożyteczny dla tych przedsiębiorców i tych systemów gospodarczych, które pierwsze do niego doszły, czyli Brytyjczyków. Okazało się, że prawie wszędzie i zawsze przyznawano ochronę celną rodzącym się gałęziom przemysłu, obecnie - artykułom pochodzenia rolniczego, i zmierzchającym przemysłom i to w państwach bogatej Północy. Natomiast polityka przemysłowa kwitła w najlepsze we wczesnym stadium rozwoju różnych gałęzi przemysłu Niemiec, Japonii, Korei, Tajwanu i kolejnych uprzemysławiających się społeczeństw. Natomiast cła na artykuły przetworzone zostały zniesione wówczas, gdy konkurencyjne na rynkach światowych kolosy - nowoczesne konglomeraty, zresztą głównie amerykańskie, w poszukiwaniu najmniejszych kosztów produkcji przewoziły materiały, komponenty i produkty między swoimi filiami i rynkami w różnych państwach ${ }^{27}$. Ale państwo może przejąć jakieś terytorium z zasobami ludzkimi i materialnymi. Po odliczeniu kosztów przejęcia - władza może wyprowadzać te zasoby za pomoca przymusowej pracy oraz opodatkowania w towarach lub pieniądzu. $Z$ drugiej stronny można władzę poszerzyć na drodze użycia kapitału pieniężnego, który kontroluje, eksploatuje oraz rozprzestrzenia łańcuchy produkcyjne oraz upowszechnia handel (Holendrzy w Indonezji, Anglicy w Indiach). Jak teraz dzięki rajom podatkowym płacą niskie podatki, a ktoś inny zapewnia porządek społeczny, bezpieczeństwo, jakość kapitału ludzkiego oraz infrastrukturę. Ciekawy przypadek to „fundusze bogactwa narodowego" jak ZEA, Norwegia, ChRL, Kuwejt, które inwestując na świecie dalej powiększają potęgę swojego państwa (jak w merkantylizmie). W rezultacie realizacji liberalnej koncepcji stosunków międzynarodowych powstał „super, hiper czy turbo kapitalizm”, w którym instytucje finansowe krajowe i międzynarodowe współdziałają w razie potrzeby z państwem. Doszło do nadproporcjalnego rozrostu sektora finansowego, określanego jako finansjeryzacja gospodarki. Obroty finansowe przekraczają obecnie PKB ponad 50-krotnie. Znaczna część operacji finansowych to transakcje tzw. krótkiej sprzedaży. W rezultacie rynek akcji zaczął determinować strategie działania korporacji, fluktuacja zaś rynku akcji stała się główną determinantą cykli gospodarczych. Jak pisze J. Żyżyński: ,usługi finansowe stały się zatem klu-

26 R. O. Keohane, J. S. Nye jr, Power and Interdependence: World Politics in Transition, Reading 2000, s. 122-132; R. O. Keohane, After Hegemony: Cooperation and Discord in the World Political Economy, Princeton 2005, s. 85-97; A. M. Kjaer, Rzqdzenie, Warszawa 2009, s. 72-116.

27 Por.: J. K. Galbraith, Ekonomia w perspektywie. Krytyka historyczna, Warszawa 2011, S. 154 . 
czową gałęzią gospodarki w krajach rozwiniętych. Mają istotny, wciąż rosnący udział w PKB i stają się ważnym źródłem miejsc pracy"28.

Instrumentem globalnego rządzenia (ang. global governance, transgovernmentalism) stał się - wedle określenia J. Williamsona - konsensus waszyngtoński. Tworzą go międzynarodowe instytucje finansowe: Bank Światowy, Międzynarodowy Fundusz Walutowy, Światowa Organizacja Handlu, OECD, ILO. Organizacje te współdziałające ściśle z rządem amerykańskim, ustaliły po 1980 roku zasady polityki gospodarczej przyjaznej rynkowi (ang. market friendly policy). Zasady te stały się na długie lata programem zmian ustrojowych $\mathrm{w}$ świecie. $\mathrm{W}$ tym splocie instytucji i idei liberalizmu instytucjonalnego odwzorowuje się główna myśl globalnego rządzenia, metarządzenia: współpraca niedemokratycznych instytucji międzynarodowych i globalnych z państwem, które dostarcza całemu przedsięwzięciu cząstkowej legitymacji demokratycznej. Jest to rządzenie wielopoziomowe i wielofilarowe. Negocjacje, ustalenia, harmonizacja interesów i oczekiwań dokonuje się w wielokącie: prowincja - państwo/ugrupowanie regionalne państw/organizacje międzynarodowe i regionalne - poziom globalny. W jego ramach powstają regulacje globalne. Na tym forum państwo amerykańskie, przedstawiciele UE przy współpracy wielkich korporacji kształtują prawo, z jednej strony chroniące monopole i rynki własnych systemów gospodarczych, z drugiej zaś wykluwają się deregulacje, oszczędzające korporacjom rozmaitych kosztów. Jak pisze W. Morawski: „rośnie znaczenie sieci dialogowych, bo jest to forma działania w sferze mikro z myślą o zapewnieniu zmian w sferze makro"29. Do tego potrzebne są sformalizowane reguły gry i struktury, w których przebiegają interakcje podmiotów uczestniczących w globalnym rządzeniu. Pozostaje otwartą kwestią czy tak rozumiane globalne rządzenie sprosta wyzwaniom, które przynosi obecna faza globalizacji. Do nich można zaliczyć: terroryzm międzynarodowy, zapobieganie rozprzestrzenianiu broni jądrowej, globalne kryzysy finansowe, ochronę globalnego ekosystemu? Trudności nastręcza też połączenie integracji ekonomicznej z anarchicznym z natury ładem politycznym. Tu mamy do czynienia z państwami o różnym mocarstwowym statusie. Kolejnym problemem jest technokratyczny charakter rządzenia globalnego. Biorą w nim bowiem udział elity globalne: eksperci, funkcjonariusze wyższych szczebli organizacji międzynarodowych, prawnicy rządowi, autorytety świata nauki. Pogłębia się tendencja antydemokratyczna. Jej przejawem jest personalizacja i tabloidyzacja polityki, a z drugiej strony - oligarchizacja i kartelizacja sceny politycznej.

Najważniejsze momenty przełomowe to przerwanie ciąłości dotychczasowych struktur społecznych: aparatu wytwórczego, organizacji społecznej, spadku roli pewnych klas społecznych, upadku państwa itd. Zmiany jakościowe dokonują się zatem w okresie kryzysów społecznych: gospodarczych, politycznych, towarzyszą im zbiorowe ruchy protestu (Tilly). Takie historyczne fazy ewolucji gospodarki kapitalistycznej opisują teorie cykli ekonomicznych. Do najważniejszych należą: teoria długich fal (Kondratiew, Braudel, Mendelson, Mandel, Schumpeter) oraz cykle koniunkturalne,

28 J. Żyżyński, Neoliberalizm - ślepa uliczka globalizacji, w: Globalizacja, kryzys i co dalej?, red. G. Kołodko, Warszawa 2010, s. 33.

29 W. Morawski, Konfiguracje globalne. Struktury, agencje, instytucje, Warszawa 2010, s. 250. 
zależne - według Keynesa - od fluktuacji krańcowej efektywności kapitału ${ }^{30}$. W odniesieniu do obecnej fazy ewolucji nowoczesnej gospodarki rynkowo-kapitalistycznej główne pytanie brzmi: czy rozpoczęty w połowie lat siedemdziesiątych XX wieku cykl to tylko kryzys finansowy czy systemowy. Pytanie to postawił już F. Braudel ${ }^{31}$.

$$
* * *
$$

Rozpoznanie związków i czynników wyjaśniających proces powstawania cywilizacji światowej i punktów zwrotnych jej ewolucji wymaga zatem strategii transdyscyplinowej. Jej stosowanie w praktyce badawczej wymaga z kolei rozległej wiedzy teoretycznej i konkretno-empirycznej, będącej dorobkiem różnych dyscyplin akademickich.

Dzięki strategii transdyscyplinowej powstaje idiograficzna teoria, rekonstruująca jednostkowy proces historyczny powstawania cywilizacji światowej, analogicznie jak nauki przyrodnicze rekonstruują dzieje Ziemi. Jednak można wykryć w tym procesie prawidłowości w relacjach między przyrodą a działalnością gospodarczą, typem gospodarki a wielkością populacji. Tak samo jak prawidłowości w życiu różnych gatunków, np. w teorii ewolucji. Dlatego na potrzeby wyjaśnienia jakiegoś zjawiska musimy uruchomić także wiedzę ogólną, konieczną do zrozumienia prawidłowości i związków między fazami procesu i elementami ewoluujących struktur społecznych. Nie ma jednej koncepcji uniwersalnej, poza zakładaniem wiedzy o człowieku i strukturach społecznych, które tworzy i które w rezultacie później kształtują jego los wraz z lokalnym ekosystemem (teraz można się uwolnić od systemu lokalnego, ale pozostają uwarunkowania na poziomie globalnego ekosystemu). Chodzi o to, że chcąc zachować globalne dobra kolektywne trzeba jednocześnie poznać przyrodnicze mechanizmy ich trwania (informacje bierzemy z dobrodziejstwem inwentarza od przyrodników, stąd komponent wiedzy przyrodniczej). Następnie trzeba wiedzieć, jakie skutki przynosi gospodarcza aktywność całej populacji ludzkiej w warunkach ładu neoliberalnego (komponent wiedzy ekonomicznej), i jak niesprawności tego ładu mogą minimalizować współdziałające ze sobą państwa (komponent wiedzy politologicznej z zakresu nauki o stosunkach międzynarodowych i globalnego rządzenia). I w końcu: jakiej zmiany stylu konsumpcji, diety, systemu wartości wymagają te strategie od poszczególnych jednostek (aspekt kulturowy). To jest istota strategii transdyscylinowej: łączenie pojęć, kategorii, tez sformułowanych w ramach różnych dyscyplin przyrodniczych i społecznych dla zrozumienia problemów teoretycznych i praktycznych, które stwarza ochrona i korzystanie z globalnych dóbr kolektywnych.

30 N. D. Kondratiew, Boszije cikty koniunktury i terorija prewidenija. Izbrannyje trudy, Moskwa 2002; J. M. Keynes, Ogólna teoria zatrudnienia, procentu i pieniądza, Warszawa 1985, s. 174-178, 350-351; E. Mandel, Long Waves of Capitalist Development: A Marxist Interpretation, London 1995; P. Dockes, B. Rosier, Cykle ekonomiczne: Kryzysy i przemiany społeczne. Perspektywa historyczna, Warszawa 1987, s. 151; L. Mendelson, Teoria i historia cykli ekonomicznych, t. II, Warszawa 1960; J. A. Schumpeter, op. cit., s. 99-105; F. Braudel, Kultura materialna, gospodarka i kapitalizm XV-XVIII wiek, t. III, Warszawa 1992, s. 62-64; M. Husson, Kapitalizm bez znieczulenia, Warszawa 2011, s. 59-69; G. Ingham, Kapitalizm, Warszawa 2011, s. 146-150; C. Kindleberger, R. Aliber, Szaleństwo, panika, krach: historia kryzysów finansowych, Warszawa 1999.

31 F. Braudel, Kultura materialna, gospodarka i kapitalizm XV-XVIII wiek, t. III, op. cit., s. 63. 


\title{
STRESZCZENIE
}

W artykule rozważany jest problem integracji wiedzy humanistycznej, koniecznej do opisu struktury i funkcjonowania współczesnej cywilizacji. Wiedza ta gromadzona jest w instytucjonalnych ramach różnych dyscyplin nauk społecznych. Paradoksalnie stosunkowo mało eksponowane miejsce w podziale pracy badawczej zajmuje nauka o stosunkach międzynarodowych. Jej domena - w dotychczasowym kształcie - jest bowiem aspekt relacji między państwami, rozumianymi jako suwerenne jednostki geopolityczne. Większe inspiracje i walory heurystyczne zawiera dorobek world history (W. McNeill, J. Goody, K. Pomerantz), makrohistorycznej socjologii (P. Burke, M. Mann, Ch. Tilly) czy teorii systemów-światów F. Braudela czy I. Wallersteina. $\mathrm{W}$ artykule przedstawiona jest w zarysie transdyscyplinowa strategia badania cywilizacji światowej.

\section{INTERNATIONAL RELATIONS THEORIES IN HUMAN KNOWLEDGE OF THE WORLD SYSTEM}

\begin{abstract}
The paper deals with the issue of the integration of humanistic knowledge that is indispensable to describe the structure and functioning of contemporary civilization. Such knowledge is collected in the institutional framework of various branches of social sciences. Ironically, the science of international relations occupies a relatively inconspicuous position in the division of research since its present form has been mainly preoccupied with the aspect of relations between states, understood as sovereign geopolitical entities. The achievements of the world history (W. McNeill, J. Goody, K. Pomerantz), macrohistorical sociology (P. Burke, M. Mann, Ch. Tilly), and the worlds-systems theory by F. Braudel and I. Wallerstein offer more inspiration and heuristic merit. The paper outlines the transdisciplinary strategy of research into global civilization.
\end{abstract}

